\title{
Quality improvement of monolithic steel fiber concrete floor slabs with void formers
}

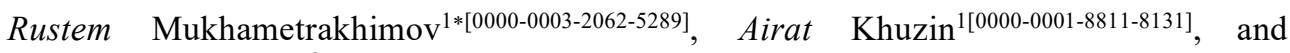 \\ Dinara Khamidullina² \\ ${ }^{1}$ Kazan State University of Architecture and Engineering, 420043 Kazan, Russia \\ ${ }^{2}$ LLC «ProjectStroyMontazh», 420087 Kazan, Russia
}

\begin{abstract}
The features of the technology for the monolithic floors construction using void formers have been studied, its disadvantages have been identified and the ways to eliminate them have been proposed. At the first stage of this work, the reasons for the low quality of monolithic floors with void formers were studied by the method of visual and measuring control, and by comparing with known scientific and industrial data. At the second stage, by the method of systematization the main defects and damages arising in the construction, repair and usage of these floor slabs were classified and ways to eliminate them were proposed. At the third stage, the features of the quality control system, carried out directly during the construction of monolithic floor slabs using void formers, were studied, the composition of operations and control tools were proposed. According to the research results, it was found that the use of steel-fiber concrete in floors with non-removable void formers allows to reduce the percentage of reinforcement by $9.82 \%$, compared to other known options, and also to reduce the consumption of concrete in comparison with a solid monolithic slab almost by half. The proposed quality control system will improve the efficiency of monolithic floor slabs using void formers.
\end{abstract}

Keywords. Concretes, lightweight monolithic floor slabs, effective design shape, non-removable void formers, fiber concrete, one-stage concreting, fixators, defects, damage, quality control, construction technology and organization.

\section{Introduction}

The advantage of the construction of monolithic reinforced concrete buildings and structures over the construction of prefabricated structures is that it allows the construction of reliable structures of almost any shape and number of storeys in a short time. However, such construction is very material-intensive, which leads to the heaviness of the building itself and its components. One of the heaviest elements with a high labor intensity of its construction is the structure of the floor. In most cases, solid floors are used, since this provides relatively low labor costs, but it also leads to a significant increase in the consumption of concrete and reinforcement, and, as a consequence, to a heavier structure. In this regard, one of the urgent

${ }^{*}$ Corresponding author: muhametrahimov@mail.ru 
tasks of increasing the efficiency of construction is to reduce the weight of building structures and material consumption while ensuring high quality of construction products.

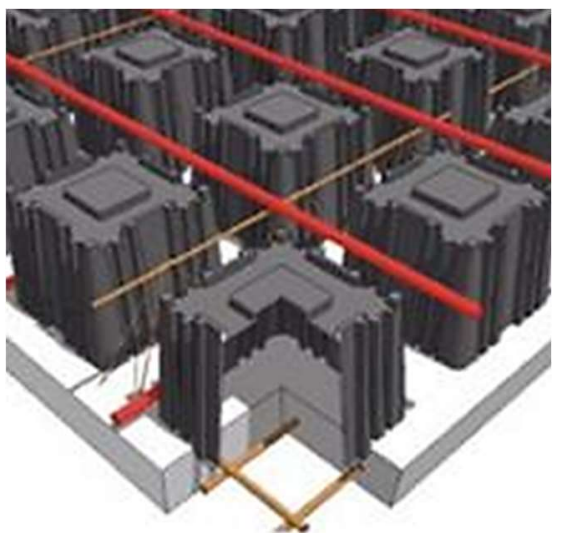

a)

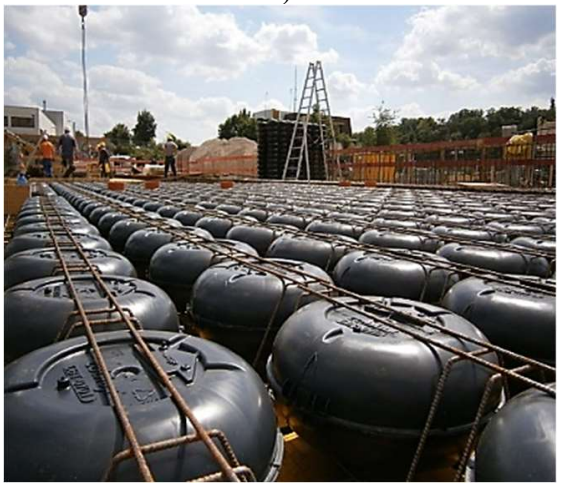

c)

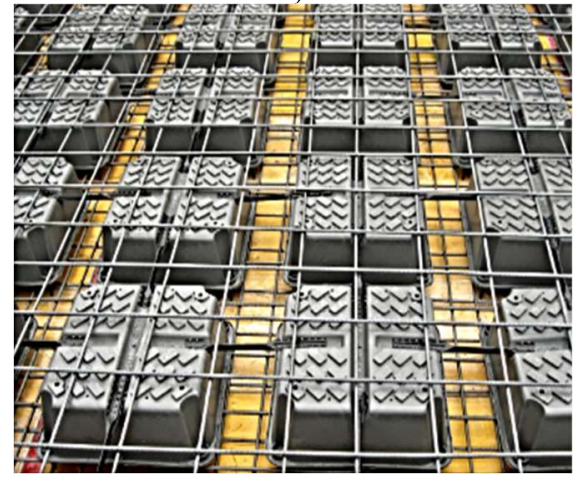

e)

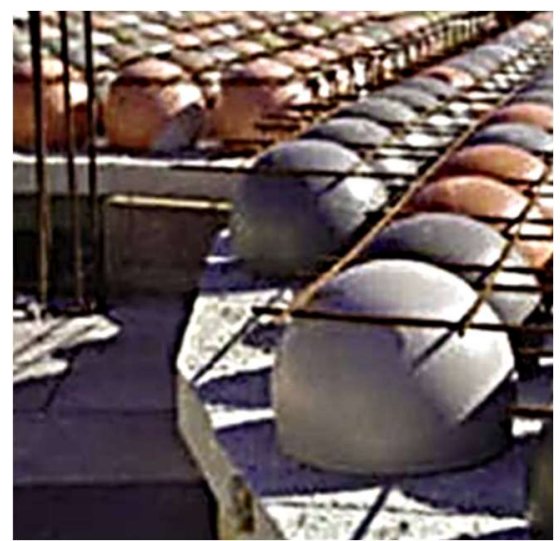

b)

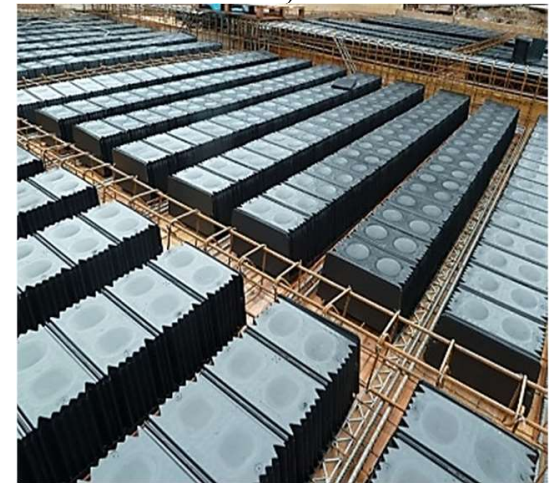

d)

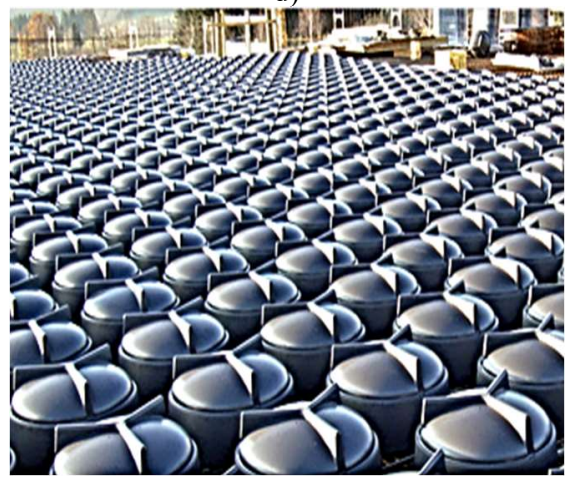

f)

Fig. 1. Types of monolithic reinforced concrete slabs with non-removable void formers: Airdeck; b) BubbleDeck; c) Cobiax; d) U-BahnBeton; e) U-BootBeton; f) Beeplate.

It is known that a reduction in the weight of building floors can be achieved by the use of new effective structural forms [1], the use of prestressed elements [2], an increase in the use of lightweight concrete on porous aggregates [3], etc.

The construction of floors of effective structural forms is the most promising, since it allows to reduce the weight of the floors by $30-40 \%$, to reduce the consumption of reinforcement by $1.3-1.5$ times, and to reduce the weight of the building itself by $25-30 \%$. The floors 
of an effective structural form include monolithic coffered slabs, slabs with non-removable void formers made of concrete, plastic, etc. These elements act as a permanent formwork by forming a space for a monolithic coffered structure, filling part of the floor structure, at the same time creating voids and reducing the weight of the floors.

Since this method is the most effective in terms of reducing material consumption and ensuring a flat ceiling surface, we will consider the use of various void formers in more detail.

In works [4-12] several types of monolithic reinforced concrete floors with non-removable void-formers are considered (Fig. 1). Their fundamental difference is the shape, dimensions and material.

The construction of monolithic reinforced concrete floors with non-removable void formers can significantly reduce the weight of the floors. Thanks to this advantage, it becomes possible to avoid protruding capitals and beams between the columns, to increase the spans between the columns and to reduce the number of them. Reducing the weight of the slabs leads to a decrease in the total load on the columns and the foundation, which leads to an optimization of the column cross-section and the thickness of the foundation slab.

Increasing the efficiency of the device monolithic steel fiber concrete floor slabs with void formers can be achieved through the use of modified concrete mixtures based on waterproof gypsum binder [13-14], cement [15-20] and mixed binders [21-23].

The purpose of this work is to improve the quality control system of technological processes for the device of monolithic steel fiber concrete floor slabs with void formers.

\section{Materials and methods}

The object of research is monolithic reinforced concrete floor slabs with void formers. The subject of the research is the construction technology and the quality control system of monolithic steel-fiber concrete floor slabs with void formers. At the first stage of this work, the reasons for the low quality of monolithic floors with void formers were studied by the method of visual and measuring control, and by comparing with known scientific and industrial data [24-29]. At the second stage, by the method of systematization the main defects and damages arising in the construction, repair and usage of these floor slabs were classified and ways to eliminate them were proposed. At the third stage, the features of the quality control system, carried out directly during the construction of monolithic floor slabs using void formers, were studied, the composition of operations and control tools were proposed. According to the research results, it was found that the use of steel-fiber concrete in floors with non-removable void formers allows to reduce the percentage of reinforcement by $9.82 \%$, compared to other known options, and also to reduce the consumption of concrete in comparison with a solid monolithic slab almost by half. The proposed quality control system will improve the efficiency of monolithic floor slabs using void formers.

To determine the geometric deviations, a set for visual and measuring control was used, which includes a steel ruler, a vernier caliper with a depth gauge, a try square, etc.

\section{Results and discussion}

\subsection{Monolithic flooring technology using void formers}

There are several technologies for the construction of floor slabs with the use of void formers. The work [13] describes a technology in which at the first stage the formwork is installed. At the second stage, the lower reinforcing mesh and the frame of the arrises of slab are laid between the void formers. At the third stage, concreting of the bottom flange of the slab is carried out. The installation of void formers should be carried out on freshly laid concrete, 
for their adhesion (development of strength of concrete more than $1.5 \mathrm{MPa}$ ), which excludes their floating during following concreting. At the fourth stage, the installation of the upper reinforcement mesh and the concreting of the upper part of the slab are performed. During this, the concrete should be placed first on the void former, then on the arrises of slab.

The disadvantage of this technology is a two-stage concreting process, because of which there are problems of ensuring the adhesion and waterproofing of the construction joint. Mechanical impact from the installation of void formers on the freshly laid concrete of the lower flange of the slab can cause defects in its structure and properties. It should be noted that the strength and crack resistance of the concrete of the lower flange of slabs is low due to its relatively small thickness. In addition, the continuity of the process of concreting the upper part of the slab is hampered by the need to place concrete first on the void former and then on the arrises of slab.

Work [14] describes a different technology, in which after the installation of the formwork and the laying of the lower reinforcing mesh and the frame of the arrises of slab, the void formers are installed, followed by the laying of the upper reinforcing mesh and concreting. Concrete is laid in two stages. At the first stage, the lower flange of the floor slab is concreted, with the technological holding for the concrete to gain strength of more than 1.5 Mpa. At the second stage, the arrises between the void former and the upper flange of the floor slab are concreted.

In addition to the disadvantages noted in the first method, in this technology, the complexity of the process of the first stage of concreting the lower flange of the floor slab should be noted. If a sufficient thickness of this layer is not ensured, the adhesion of the void formers will not occur, which will lead to their floating up during the second stage of concreting. Excessive thickness of the first layer will make the void formers float up, which will move them from their specified permanent position.

The third method of constructing monolithic floors using void formers [15] allows the transition to one-stage concreting for the entire thickness of the floor slab through the use of special fixators that ensure the permanent position of the voids when they float up during concreting. The technology for constructing a floor slab according to this method includes the following processes: installation of formwork, laying of the lower reinforcing mesh and frame of arrises, installation of void formers, installation of void formers fixators, laying of the upper reinforcing mesh, concreting in one layer.

The disadvantage of this method is the need to drill holes in the formwork for the fixing brackets, which increases the labor intensity of the work and leads to rapid wear of the floor formwork.

In our opinion, this technology for the construction of monolithic floors with the use of void formers is the most effective, since it is carried out in one-stage concreting, but, despite this, the lower flange of floor slabs has relatively low strength and crack resistance due to its small thickness. Also, the disadvantage is the lack of the necessary regulatory framework in Russia for the calculation, design, manufacture and installation of monolithic floors with the use of void formers and a production base for their production.

\subsection{Elimination of the disadvantages of monolithic floors using void formers and special fixators}

To eliminate the lack of strength and crack resistance of the lower flange of floor slabs, the authors propose the use of steel fiber concrete mixtures during concreting. It is known [16] that mixing steel fibers in concrete in an amount of 20-50 kg per $1 \mathrm{~m}^{3}$ increases the tensile strength in bending by 2-3 times, compression by $10-50 \%$, axial tension by $50-80 \%$, impact viscosity by $8-10$ times, modulus of elasticity by $20 \%$, crack resistance by $2-3$ times, durability by 2 times. Frost resistance and water resistance are increased by no less than a 
class. This will additionally reduce the consumption of reinforcement in reinforced concrete structures, which compensates for the rise in prices associated with fibers.

To compare the material consumption of a solid monolithic reinforced concrete slab, a monolithic reinforced concrete slab with non-removable void formers and a monolithic steelfiber concrete slab with non-retrievable void formers, calculations were made for the limiting states of the first and second groups according to SP 52-101-2003 (Russian standard) in accordance with the requirements of paragraphs. 6.1.1-6.1.10. For example, a part of the floor slab using the DaliformGroup technology for the U-BootBeton system with dimensions in plan $1.44 \times 1.44 \mathrm{~m}$ was adopted.

According to the results of calculations, the use of a monolithic steel-fiber-concrete floor with non-removable void formers allows to reduce the percentage of reinforcement by $9.82 \%$, compared with other investigated options, to reduce the consumption of concrete in comparison with a solid monolithic slab by almost 2 times.

An important criterion for achieving the effectiveness of monolithic slabs with nonremovable void formers is their technology compliance, which is achieved by quality control at the stages of pre-installation, operational and acceptance control. At the next stage of research, the main defects and damages of monolithic floors with non-removable void formers and the reasons for their occurrence were studied. The composition of operations and means of monitoring the processes of the floors constraction are proposed.

\subsection{Main defects and damages of monolithic slabs with non-removable voids}

At this stage, the most typical defects and damages arising during the construction and usage of monolithic floors made of fiber-reinforced concrete with non-removable void formers, as well as the reasons for their occurrence, are considered (Table 1).

Table 1. Typical defects and damages arising during the construction of monolithic floors with nonremovable void formers and the reasons for their occurrence.

\begin{tabular}{|c|c|l|}
\hline Element of construction & \multicolumn{1}{|c|}{ Defects and damages } & \multicolumn{1}{c|}{ Causes of occurrence } \\
\hline Formwork & $\begin{array}{c}\text { Slots in butt joints, deviations } \\
\text { from design dimensions }\end{array}$ & $\begin{array}{l}\text { The use of non-certified products; } \\
\text { discrepancy between the geometric } \\
\text { parameters of the products; non-com- } \\
\text { pliance with the design dimensions } \\
\text { during installation, improper fas- } \\
\text { tening of } \\
\text { formwork panels }\end{array}$ \\
\hline Reinforcement & $\begin{array}{l}\text { Inaccurate installation of rein- } \\
\text { forcement products, corrosion } \\
\text { of elements, poorly performed } \\
\text { welding of frame connections }\end{array}$ & $\begin{array}{l}\text { The use of non-certified products; ex- } \\
\text { posure to aggressive environments; } \\
\text { fitters' lack of appropriate qualifica- } \\
\text { tions }\end{array}$ \\
\hline Coupling for fastening & $\begin{array}{l}\text { Corrosion of elements, incon- } \\
\text { sistency of geometric parame- } \\
\text { ters }\end{array}$ & $\begin{array}{l}\text { The use of non-certified products; vi- } \\
\text { olation of the rules of transportation } \\
\text { and storage; mechanical impact; lack } \\
\text { of a protective coating; exposure to } \\
\text { aggressive environments }\end{array}$ \\
\hline Void formers & Displacement in horizontal \\
and vertical directions & $\begin{array}{l}\text { The use of non-certified products; } \\
\text { discrepancy between the geometric } \\
\text { parameters of the products; non-ob- } \\
\text { servance of design dimensions during } \\
\text { installation }\end{array}$ \\
\hline Fiber concrete & Mixture inhomogeneity & $\begin{array}{l}\text { Violation of production technology; } \\
\text { violation of concreting technology; }\end{array}$ \\
\hline
\end{tabular}


As you can see from the table. 1, the most common reasons for the appearance of defects and damages during the construction of these floor slabs are associated with the lack of control of operations at the stages of preparatory works, installation of void formers, acceptance of completed work.

\subsection{Quality control during the installation of void formers and fixators}

Operations and means of control at the preparatory stage, during the installation and acceptance of completed work during the installation of void formers and fixators are given in table. 2.

Table 2. Operations and means of control.

\begin{tabular}{|c|c|c|c|}
\hline Work stages & Controlled operations & $\begin{array}{c}\text { Control } \\
\text { (method, scope) }\end{array}$ & Documentation \\
\hline $\begin{array}{l}\text { Preparatory } \\
\text { work }\end{array}$ & $\begin{array}{l}\text { Control: } \\
\text { - availability of a documentation on the } \\
\text { quality and compliance of the charac- } \\
\text { teristics of the void former with the de- } \\
\text { sign ones; } \\
\text { - surface quality, accuracy of geometric } \\
\text { parameters, the appearance of void for- } \\
\text { mers, couplings and fixators; } \\
\text { - the presence of the work acceptance } \\
\text { certificates of previously performed } \\
\text { works; } \\
\text { - cleaning of the supporting surfaces of } \\
\text { the previously mounted and lifted void } \\
\text { formers from debris, dirt, snow and ice; } \\
\text { - the presence of orientating marks that } \\
\text { determine the design position of the } \\
\text { mounted liner. }\end{array}$ & $\begin{array}{c}\text { Dimensional, } \\
\text { each element } \\
\text { Visual } \\
\text { Visual } \\
\text { Visual }\end{array}$ & $\begin{array}{l}\text { Certificate of } \\
\text { approval, gen- } \\
\text { eral works log, } \\
\text { work ac- } \\
\text { ceptance certif- } \\
\text { icates of com- } \\
\text { pleted works. }\end{array}$ \\
\hline $\begin{array}{l}\text { Void formers } \\
\text { installation }\end{array}$ & $\begin{array}{l}\text { Control: } \\
\text { - installation of void formers in the de- } \\
\text { sign position: deviation from the axis in } \\
\text { the longitudinal and transverse direc- } \\
\text { tions - control of the installation of cou- } \\
\text { plings (horizontal deflection) and con- } \\
\text { trol of the lheight (vertical deflection); } \\
\text { - installation of void formers fixators. }\end{array}$ & Dimensional & $\begin{array}{c}\text { General works } \\
\log \end{array}$ \\
\hline $\begin{array}{l}\text { Acceptance of } \\
\text { completed } \\
\text { works }\end{array}$ & $\begin{array}{l}\text { Verify: } \\
\text { - the actual position of the mounted } \\
\text { void formers; } \\
\text { - the appearance of the front surfaces; } \\
\text { - bearing capacity of the void former. }\end{array}$ & $\begin{array}{l}\text { Dimensional } \\
\text { Visual } \\
\text { Dimensional }\end{array}$ & $\begin{array}{l}\text { Work ac- } \\
\text { ceptance certif- } \\
\text { icates of com- } \\
\text { pleted works, } \\
\text { as-built survey } \\
\text { map }\end{array}$ \\
\hline \multicolumn{4}{|c|}{ Control and measuring tool: plumb rail, building level, metal ruler, level, theodolite. } \\
\hline $\mathrm{O}$ & 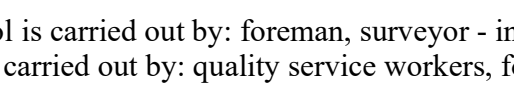 & $\begin{array}{l}\text { process } \\
\text { an, own }\end{array}$ & $\begin{array}{l}\text { cceptance con- } \\
\text { tor. }\end{array}$ \\
\hline
\end{tabular}

Technical requirements:

a) the geometric dimensions of the void formers must meet the requirements given in Fig. 2 . 


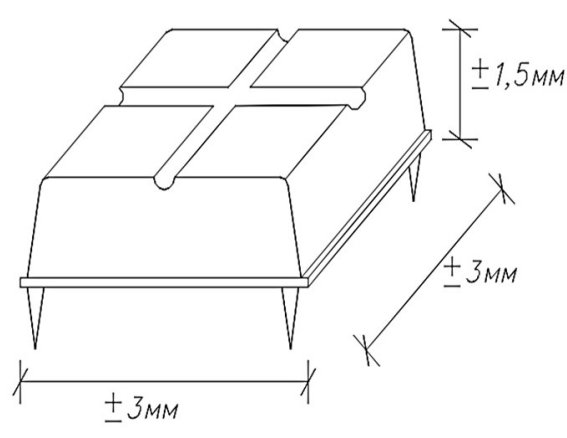

a)

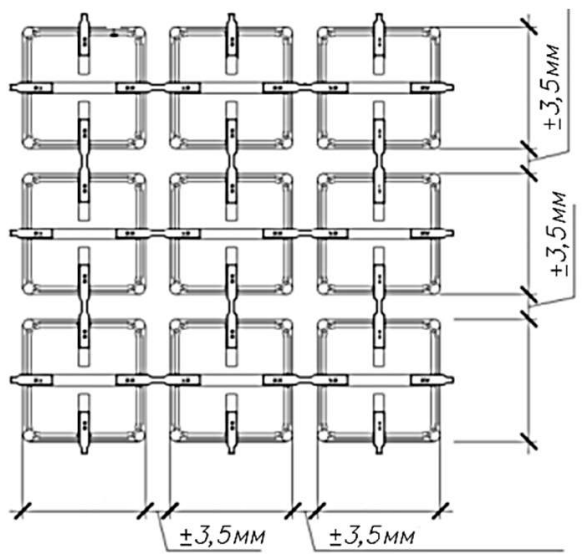

b)

Fig. 2. Technical requirements for the geometric dimensions of the void formers: a) permissible deviations of the geometric dimensions of void formers along the length, width and height; b) permissible deviations of the distance between void formers for longitudinal and transverse beams.

b) Requirements for the quality of the materials used and acceptance.

The material of void formers must meet the requirements of regulatory documents for this type of products. Void formers must have strength, rigidity, shape invariability and stability in position, in the conditions of installation and transportation.

Void formers must be firmly fixed to each other using couplings when laying out. It is not allowed to use damaged void former during installation - cracks, defect of the leg, imbalance of the void former, skewed void former, as well as replacing them with another one without making changes to the design documentation.

When accepting the formwork, it is necessary to verify the presence of documentation with instructions for the installation and usage of the void former, verify the geometric dimensions, the quality of the surfaces.

During the installation of the void former, the bearing capacity of their upper side should be measured. The permissible vertical distributed load on the upper side of the void former (for a dimension not exceeding $43 \times 43 \mathrm{~cm}$ ) is not more than $1.2 \mathrm{tf} / \mathrm{m}^{2}$.

\section{Conclusions}

1. Based on the review of literature, various technologies for the construction of monolithic floors with the use of void formers are considered. Their advantages and disadvantages are revealed. It was revealed that the most effective technology is the one with the use of special fixators, which allow concreting the floor slab for the entire thickness in one stage, which was adopted for further research.

2. Based on the revealed disadvantages of the studied technology, such as low strength and crack resistance of the lower flange of floor slabs, it was proposed to use steel-fiberconcrete mixtures during concreting.

3. Based on the results of the calculations, it was found that the use of steel-fiber concrete in floors with non-removable void formers allows to reduce the percentage of reinforcement by $9.82 \%$, compared to other investigated options, to reduce concrete consumption in comparison with a solid monolithic slab almost by half.

4. The main defects and damages arising during the construction and usage of monolithic steel-fiber-reinforced concrete slabs with non-removable void-formers are identified and the main causes of their occurrence are established. Operations and control means are proposed. 


\section{References}

1. A.A. Folomeev. Reduction of material consumption of reinforced concrete structures. M.: Stroyizdat, 66 (1974).

2. A.A. Voevodin. Prestressed systems of structural elements. M.: Stroyizdat, 304 (1989).

3. I.A. Ivanov. Light weight concrete on artificial porous aggregates. M.: Stroyizdat, 182 (1993).

4. S.A. Bugaevskiy. Modern lightweight reinforced concrete floors with the use of nonremovable void-form liners, Naychniy vestnik stroitelstva 692, 74-75 (2015).

5. AirDeck System // airdeck.com: official site AirDeck System. 2013. URL: http://www.airdeck.com/ (reference date: 16.03.2018).

6. Tina Lai. Structural Behavior of BubbleDeck Slabs and Their Application to Lightweight Bridge Decks, International Journal of Civil Engineering and Technology 45, 54 (2017).

7. Mike Mota. Voided two-way flat plate slabs, Structure magazine 7, 7 (2009).

8. A.G. Churakov. Biaxial hollow slab with innovative types of voids, Stroitelstvo unikalnih zdaniy I soorujeniy 6 (21), 70-88 (2014).

9. A.H. Karapetyan. Cobiax technology: cost - effective- environmentally friendly - fast, Vestnik Rossiyskogo soyuza stroiteleiy 2, 20-21 (2013).

10. Cobiax Technologies AG // cobiax.com: official site Cobiax. 2014. URL: http://www.cobiax.com/startseite (reference date: 17.03.18).

11. DALIFORMgroup // daliform.com: official site DALIFORM. 2014. URL: http://ru.daliform.com/prodotti/categorie.php (reference date: 18.03.18).

12. Beeplate System // beeplate.com : official site Beeplate System. 2014. URL: http://www.beeplate.com (reference date: 18.03.18).

13. Use the Insert Citation button to add citations to this document.

14. Production technology of lightweight reinforced concrete: patent 69346 of the Ukraine, № 201112222 ; decl. 18.10.2011; publ. 25.04.2012, Bull. in № 8.1 p.

15. M. Khaliullin, A. Dimieva. Composite gypsum binder under introducing thermally activated clay as a pozzolanic component and adding ground limestone, IOP Conference Series: Materials Science and Engineering (2020). DOI: 10.1088/1757899X/890/1/012093.

16. M. Khaliullin, R. Rakhimov, I. Faizrakhmanov. The influence of thermally activated clay additives on the properties of composite gypsum binder, ZKG Zement - kalk - gips Int. Bauverlag BV GmbH. Gutersloh, 58-63 (2017).

17. P.E. Bulanov, E.U. Ermilova, L.F. Mavliev. Structure and mineral composition of soilcement with complex additive, Mag. Civ. Eng. 83, 38-48 (2018). DOI: 10.18720/MCE.83.4.

18. E. Ermilova, Z. Kamalova, R. Ravil. Influence of clay mineral composition on properties of blended portland cement with complex additives of clays and carbonates, IOP Conference Series: Materials Science and Engineering. Institute of Physics Publishing 890, (2020). DOI: 10.1088/1757-899X/890/1/012087.

19. V. Khozin, O. Khokhryakov, R. Nizamov. A «carbon footprint» of low water demand cements and cement-based concrete, IOP Conference Series: Materials Science and Engineering, (2020). DOI: 10.1088/1757-899X/890/1/012105.

20. N. Krasinikova, S. Stepanov, D. Makarov. Cement stone, modified by chemical water treatment sludge, IOP Conference Series: Materials Science and Engineering 890, (2020). DOI: 10.1088/1757-899X/890/1/012099.

21. S.I. Pimenov. Heavyweight concrete based on hydromechanochemically activated binder, IOP Conference Series: Materials Science and Engineering 890, (2020). DOI: 10.1088/1757-899X/890/1/012098.

22. S. Stepanov, N. Krasinikova, D. Makarov. Cement stone, modified by galvanic sludge, 
IOP Conference Series: Materials Science and Engineering 890, (2020). DOI: 10.1088/1757-899X/890/1/012086.

23. E.A. Vdovin, V.F. Stroganov. Modification of cement-bound mixtures with sodium formate additives for the construction of pavement bases at low air temperatures, IOP Conference Series: Materials Science and Engineering 786, (2020). DOI: 10.1088/1757899X/786/1/012065.

24. L. Mavliev, E. Vdovin. Structure of road soil cement compositions modified by complex additive based on organosilicon compounds and electrolytes, E3S Web of Conferences (2019). DOI: 10.1051/e3sconf/201914002016.

25. D. Smirnov, E. Yagund, F. Zamaliev, V. Brodneva. Estimation of impacts of cellulosic admixtures on sma features, IOP Conference Series: Materials Science and Engineering. Institute of Physics Publishing 890, (2020). DOI: 10.1088/1757-899X/890/1/012102.

26. R. Mukhametrakhimov, I. Aliullova. Construction technology and quality control of expansion joints with rubber compensators, E3S Web Conf. 264, 02066 (2021). DOI: $10.1051 / \mathrm{e} 3$ sconf $/ 202126402066$.

27. R. Mukhametrakhimov, A. Galautdinov, A. Panchenko, T. Gorbunova. Improving the quality of installation of preinsulated pipelines of heat supply systems, E3S Web Conf. 264, 02068 (2021). DOI: 10.1051/e3sconf/202126402068.

28. R.K. Mukhametrakhimov, A.A. Panchenko. Features of technology of installation and quality control of pipelines with polyfoam polyethylene insulation, Izv. KGASU 2, 246254 (2018).

29.27. Mukhametrakhimov, R.K., Aliullova, I.R.: Improvement of the quality control system for expansion joints with rubber compensators during the repair of bridge constructions. Izv. KGASU. 3, 47-55 (2020).

30. R.K. Mukhametrakhimov, L.V. Lukmanova, M.I. Kamaliev. Features of the quality control system of the installation of hinged ventilated facade systems, Izv. KGASU $\mathbf{1}$, 234-240 (2018).

31. A. Khuzin, A. Sharavina. Ways to improve the quality of monolithic reinforced concrete structures, IOP Conference Series: Materials Science and Engineering 890, (2020). DOI: $10.1088 / 1757-899 X / 890 / 1 / 012127$.

32. Production technology of lightweight reinforced concrete: patent 75556 of the Ukraine, № 201204865; decl. 18.04.2012; publ. 10.12.2012, Bull. in № 23. 2 p.

33. Production technology of multi-cavity reinforced concrete monolithic plate: patent 65670 of the Ukraine, № 20023032057; decl. 07.03.2003; publ. 15.12.2003, Bull. in № 12.1 p.

34. V.S. Izotov, R.K. Mukhametrakhimov, L.S. Sabitov. Experimental studies of the efficiency of dispersed reinforcement of the stretched zone of concrete bending elements, Nauchniy gurnal stroitelstva i arhitekturi 1, 119-125 (2010). 